\title{
Chiaraje, Mikayo, Tocto: rituális harcok a perui Andokban (Kardulesz Rita) ${ }^{2}$
}

Rituális küzdelmek Afrikától Indonéziáig a világ számos pontján ismertek. Ezek a rituális találkozások a legtöbbször nem „teátralizált” vagy imitált harcok, hanem valóságosan véres összecsapások. A versengések ôseredete különbözô okokra vezethetô vissza: lehet mitológiai, gazdasági vagy egy történelmi esemény újraélése, határproblémák, vagy akár személyes konfliktusok rendezése.

Dél-Amerikában is több közösség ismétel meg évrôl évre hagyományból gyökerezô, ún. harci rítusokat. A perui Andok Cusco megyéjének magasan fekvố tartományaiban több ilyen rítus is megtalálható. Az én kutatási területem 2003-2004-ben Canas tartomány fennsíkjain volt 4700 méter magasan, ahol a Chiaraje, Mikayo és a Tocto elnevezésú küzdelmeket vizsgáltam. Bizonyos andoki pampákon egymással szomszédos falvak közösségei küzdenek meg az év meghatározott napjain. Mesztic és indián férfiak, vegyesen. A csaták fố harci fegyverei: a parittyák és a kövek, melyekkel már a prehispán idókben az Inkák is harcoltak.

Ezek az alkalmak számos sebesültet és nemritkán halálos áldozatokat követelnek.

A témáról elôször Magyarországon élö perui barátaim meséltek. Lázasan próbáltam felkutatni az erról szóló tanulmányokat, de csak igen csekély számban találtam, azok is leginkább a hatvanas-nyolcvanas, illetve a kilencvenes években láttak napvilágot. Mivel friss szakirodalom nem állt rendelkezésemre, még inkább kíváncsivá tett,

\footnotetext{
${ }^{2}$ A jelen tanulmány elkészítéséhez felhasználtam a pesti kulturális antropológia szakon írt szakdolgozatom.
} 
hogy az utóbbi években a turizmus felerôsödô hullámai és maga a globalizáció milyen mértékben befolyásolják a közösségi eseményt. Az alapkérdés pedig adta magát: milyen motivációk hajtják önként a küzdelembe az egyébként békésen egymás mellett élô falusi emberek csoportjait, miért akarják egymás vérét és halálát?

\section{A terep bemutatása}

Cusco megye, akár az Andok más megyéi, tartományokra, azon belül körzetekre, föld- vagy faluközösségekre (comunidad, kecsuául: allyu), ezeknek a zónától távol esô, néhány család által lakott egyes földterületeire (anexo), és tanyákra, azaz a közösségbe nem tartozó családok lakhelyeire osztható fel. A maradék területeken földbirtokok vagy a nagyobb tavak találhatóak.

Közigazgatásilag a nagyobb településekhez tartoznak a vonzáskörzeteikben elhelyezkedô földközösségek, tanyák, együtt pedig a körzetekhez, melyek a tartományt, összességében pedig magát a megyét képezik.

Canas körzeteinek száma nyolc: Yanaoca, Checca, Langui, Layo, Quehue, Kunturkanki, Túpac Amaru és Pampamarca. Egy 2003-as hivatalos adat szerint ezeken a területeken 51 földközösség van bejelentve. Ugyanezen a területen az INEI által feldolgozott adat szerint 1994-ben 61 földközösséget számlált a tartomány: Checca (9), Kunturkanki (8), Langui (8), Layo (6), Pampamarca (3), Quehue (4), Tupac Amaru (8), Yanaoca (15).

A tartomány településeinek szerkezetével kapcsolatban a centralizált szerkezetú települések mellett megfigyelhetô egy szétszórt, azaz diszperzív jelleg. Fôleg Checca körzetére jellemzô a lakóhelyek nagyarányú szétszóródása, azaz jelentôs távolságok egymástól, és a központi településtôl. Mindez problémákat generál, mely felhívja a figyelmet az alapszolgáltatások nehézségeire és hiányosságaira az 
érintett területeken: vízvezetékek, csatornázás, elektromosság, közlekedés stb., vagy az egészségügyi szolgáltatás és oktatás elérhetôsége. A legtöbb rendel ô a központi településeken van és elenyészô számban egyes földközösségekben. Még nem mindenhol múködnek telefonvonalak, ezért távolabb esố földközösségek, amelyek nem rendelkeznek rendelốvel, segítséget gyakran már csak késốn kapnak. Közösségi gyógyszertárak sincsenek. Az analfabétizmus 32.1\%-os a tartományban (a 40 éves és idôsebb népesség többnyire írástudatlan). A legtöbb közösségben nem megoldott az infrastruktúra: a diákoknak néha hatalmas távolságokat kell gyalog megtenniük az iskoláig. A tanárok gyakran nem képesítettek, előfordul, hogy nem adják le az órájukat, nincs ebédlô, tanári szállás, rendes étkeztetés, könyvtár, hiányosak a munkaeszközök, felszerelések még lehetne folytatni a sort.

Canas megyében az elsôdleges gazdasági tevékenység az állattenyésztés, de emellett a földmúvelésnek is nagyon fontos szerepe van. A közösségi földeken kívül általában mindenkinek van saját parcellája, amit megmúvel. A magasabb részeken: burgonyát, lóbabot, árpát, búzát és egyéb, ôsi gabona- és (quinua, quiwicha) és gumós növényeket (oca, olluco) termesztenek. A kukorica az alacsonyabban fekvố földeken terem meg.

A vetés és az aratás a két legintenzívebb mezôgazdasági munka. A vetési idôszak augusztus és november között (quinuát, árpát és búzát decemberben is) valósul meg, de vannak olyan családok, akik már júliusban elkezdik a burgonya ültetését. Az aratás és a betakarítás áprilistól júniusig tart. Januártól márciusig kevésbé megfeszített a munka, aminek okán egy idôszakos migráció indul meg a központi településekre, vagy a nagyobb városokba.

Az etnikai megosztás szerint az Andok területén az ôshonos népesség, azaz az indiánok, és a gyarmati idôszaktól kezdve a fehérekkel keveredett indiánok leszármazottai, a meszticek élnek. Nemcsak biológiai, hanem „egyszerre etnikai és társadalmi rétegzódési kategóriák” (Letenyei 1998:87). Kulturális kategória is, hiszen nem ment végbe 
teljes vérkeveredés az Andokban, ezért „kulturális meszticizálódásról” beszélhetünk. A kulturális identitás közti különbségek az Andokban nagyon hangsúlyosak: „a »szokásos « városi-paraszt ellentétet itt a nyelvi és etnikai elemek is átszövik. Kissé leegyszerúsítve: a »vidéki « indiánt jelent a »városi « pedig meszticet vagy kreolt (Peruban született fehér), azaz a fehér-mesztic világot” - folytatja Letenyei (1998:88). Egy másik etnikai kategória a „cholo”, a paraszti sorból kiemelkedett „városi indián”, aki már városban, városi ember szokásai szerint él, nem hord népviseletet, de tud kecsuául és magáénak vallja az óshonos identitás számos elemét, bár már nincs indián identitása.

A társadalmi és kulturális különbség a hegyvidéken is jól érzékelhetố a nyelvhasználatban, öltözködésben, vagy gazdasági tevékenységben. A hegyvidék városias településein élố meszticek indián környezetben élnek, gyakran folytatnak közös tevékenységet velük, például a piacokon, és sokan kétnyelvúek, azaz beszélik az indiánok nyelvét, a kecsuát, amit a velük való kommunikációban alkalmaznak. Mindez mutatja, hogy a meszticek és indiánok világa nem teljesen elszigetelve létezik egymás mellett, a kettô hatással van egymásra. A meszticek életkörülményei jobbak. Egyesek földet is birtokolnak állatállománnyal, ezekre bérezés ellenében az indián pásztorok vigyáznak.

Az indiánok általában földközösségekbe tömörülnek. Ezek a comunidadok, elszigetelôdve a mesztic kultúrától, kis szigetei az ôsi hagyományos értékeknek, s ez egyfajta védekezés is a külsô hatásokkal, modernizációval, a kultúravesztéssel szemben. Ébren tartva a tradíciót, a szokásaikat, kulturális értékeket mentenek át a közösségeken belül, így erôsítik identitásukat. A kölcsönös segítségnyújtás fontos része a közösségi szervezetüknek. Két formája van, az ôsi ayni és a minka: a „ma én megyek dolgozni a te földedre, és ha holnap nekem kell segítség, te jössz” az ayni, a „segítek dolgozni a földeden, cserébe ellátsz a napi betevôvel" pedig a minka lényege. A reciprocitás elve nemcsak a munkában, hanem az istenekkel való kapcsolatban (áldozat), a házasságon belül, és a harci küzdelmeknél (egymás támogatása) is jelen van. 


\section{A rítusok leírása}

A három rítus, azaz a Chiaraje, a Mikayo és a Tocto azonos módon épül fel:

1. Előkészítô fázis

2. Bevezetô-küzdelmi fázis

3. Pihenô-felkészülő fázis

4. Lezáró-küzdelmi fázis

1. A csata reggelén az asszonyok összekészítik az elemózsiát és az italokat, például a chichát, az erjesztett kukoricasört. A részt vevô férfiak magukhoz veszik fegyvereiket (parittya szinte mindenkinél van, de más, házilagos fegyverek is elôfordulnak, például kötél végére felerôsített vasnehezék a közelharchoz), és elindulnak a pampára. Ki gyalogosan, ki lóháton. Kis csoportok verôdnek össze az út alatt, kibeszélik, megvitatják a tavalyi küzdelmet, latolgatnak, vajon ki az esélyesebb, mennyien jönnek el. A Chiaraje küzdelmi rítusára a legtöbben kisbuszokkal érkeznek. Az elmúlt évtizedben végbement infrastrukturális fejlődés következtében az úthálózat kiépítése lehetóvé tette a forgalmat: az utasokkal megpakolt kisbuszok a quehuei oldalon már könnyúszerrel felkapaszkodnak egészen a „nézótérig”, azaz a csata pihenôhelyéig. Ez hozzájárul ahhoz, hogy a turisták és kereskedôk száma évrôl évre szaporodik.

Mindhárom rítusnak reggelén a lovasok a legszebb lószerszámokkal, nyergekkel díszítik lovaikat. A serdülô fiúk és lányok is legdíszesebb hímzett ruháikat veszik fel erre az alkalomra. A bandák tagjai élénkszínú uniformisaikat viselik, ezek a bandatagság és szövetség szimbólumai.

A gyerekek lószórból font parittyáikkal már hetekkel a küzdelem elôtt elkezdenek gyakorolni. Az apák átadják tapasztalataikat, hogy minél egyenesebben és erôsebben tudjanak hajítani. A legtöbben 
egyébként már egész kicsi koruktól, az állatok terelésénél elsajátítják a parittya forgatását.

A házaknál a rítus hajnalán vagy az azt megelôzó éjszakán a kecsua nyelvú indiánok áldozatot mutatnak be a Földanyának. A rituális csomagokat mindenféle mágikus-szimbolikus elemekbôl állítják össze, hogy késóbb elégethessék. A hamvak egyesülnek a földdel, mellyel Pachamamához, a Földanyához fohászkodnak a másnapi szerencséért, a kokalevelek rituáléjával pedig az Apukat, a hegyek szellemeit igyekeznek megnyerni.

2. A rítusok helyszínén a hangulat úgy déleloótt 11-kor kezd el fokozódni ${ }^{3}$, feszültség súrúsödik a levegôben. Vamos a la guerra! „Menjünk háborúzni” felkiáltásokkal ösztönzik egymást a harcosok. Majd az inzultusok ordításával kezdetét veszi az elsô félidô, melynek kecsua neve wayna akulli (,az elsô kokalevelek rágása”).

A lovasság nyitja meg a küzdelmet, sértésekkel ösztönzik, hergelik a másik felet a küzdelemre: „Te kutya, gyere küzdeni, ha férfi vagy!”, „Ne bújj az asszonyod szoknyája mögée!" Ez a gúnyolódás eltart egy ideig, aztán egyszer csak elindul a menet. A felek között kezdetben marad egy fix, úgy 30 méteres lövéstávolság, majd a harci kiáltások közepette felhangoznak a puskaropogásra emlékeztetô kövek tompa puffanásai.

A Chiarajén a quehuei dombtetôn eközben folyik a kirakodóvásár. A nézôk élénk figyelemmel követik a harc alakulását: dominále valamelyik fél a másik területén? Az asszonyok és a hajadon lányok, a domboldalon ülve vagy állva aggódnak hozzátartozóikért: vajon visszakapják-e ôket élve? A bátrabb megfigyelók közelebb merészkedhetnek az összecsapás színteréhez, melyek a bázisoktól 200-300 méterre találhatók. Közelebb viszont nagyobb az esély, hogy eltalálnak, ha hiфtelen támadásba lendül az ellenkezô oldal. Minden-

\footnotetext{
${ }^{3}$ A 2005-ös Toctón késôbb, délután kettổ körül kezdték csak el a küzdelmet.
} 
képpen résen kell lenni, és még idejében el kell futni. A Chiarajén és a Toctón a nốk nem mehetnek közel, mert a hiedelem szerint balszerencsét hoznak, és a sereget csak hátráltatnák. Nagyon fordulatos a küzdelem, nem lehet mindig kiszámítani, melyik fél és milyen gyorsasággal fog hirtelen behatolni a másik térfelére.

A félidô végén, délután egy-két óra körül közös egyetértésben visszavonul mindkét fél a maga dombjának tetejére, hogy egy kicsit lazítsanak, egyenek, igyanak, hogy újult energiákkal vághassanak a küzdelem végsố fázisába. Többen térnek vissza vérzô, felszakadt szájjal, halántékkal, hiszen a leggyakoribb sérülések a fejet érik.

A rituális találkozás alatt néhány hajadon, fiatalasszony idônként körtáncokat táncol, és közben a pinkuyllu hangszer szent dallamaira bátorító, ösztönzố dalokat énekelnek kecsua nyelven. Az ôsi inka furulya melankólikus hangja Arguedas szerint „ködbe borítja az agyakat, felizgatja az embereket, elszabadítja eróiket, a halállal is dacolnak". (1973:111) Kézen fogva, egyszerú lépésekben keringenek, a férfiak szökellnek is, ami az örömöt szimbolizálja. A fiatal fiúk gitárt, bandurriát, charangót szólaltatnak meg.

3. A pihenô idején társaimmal mi is bekapcsolódtunk a közös étkezésbe, hívtak több helyrôl is, tartsunk velük, a poncsókra kikészített élelmükboól kínáltak a helyiek. A férfiak az ánizslikórös, nádpálinkás vagy kukoricasörrel teli poharat nyújtották felénk, ami szertartásosan körbejárt közöttük, és amelybôl az elsố korty mindig a Földanyát illeti. Általában három óra tájt megkezdôdik a harc második félideje. Újból lendülnek a parittyák, fellobban a harci túz. Füttyszó, kiabálások és a szellemes inzultusok közepette lovak nyargalnak, embercsapatok vonulnak összemérni ügyességüket. A küzdelem már nagyobb erốbedobással zajlik, hiszen ilyenkor az egyik félnek végképp dominálnia kell, be kell hatolnia a másik területére.

„Ez egy szokás, játék, minden évben elmegyünk küzdeni, mint annak idején nagyapáink és az ô nagyapáik. Ebben a játékban normális, ha 
megölnek, nincs következmény.”, vagy: „Itt még az elnököt sem tisztelnék” tudom meg az emberekkel beszélgetve a rítus pihenóhelyén.

A Chiaraje mindkét térfelén egy-egy antenna magasodik. Ezek felállítása ellen lázadások törtek ki a területen, hiszen ez a szent hegy meggyalázásának számít. A rítusok színhelyének környezete is szent: a hegyek, a csúcsokhoz vezetố utak, a pihenôhelyek, vagy ahol táncolnak. Ezek egyben stratégiai pontoknak is számítanak.

A hivatalos szervek nem szólnak bele a küzdelembe, nincs igazságszolgáltatás. A történelem folyamán azért próbálták bojkottálni egyes kormányok alatt, de a harcosok összefogtak, megfélemlítették és elkergették a hatóságokat. ${ }^{4}$

A Chiarajén a quehuei oldalon található meg a legnagyobb fogyasztói kínálat: a lábasok, konyhai kiegészítôk, és népmúvészeti termékek mellett kondérokból lehet választani a különbözó meleg ételek közül. A kis csoportok elkülönülése baráti vagy rokoni alapon történik.

2005-ben Checca önkormányzata a polgármesterrel együtt érkezett. Étellel és itallal járultak hozzá embereik lelkesítéséhez. Én kokával és dohánnyal kedveskedtem. Ezt szívesen fogadják. Mások kérték, hívjam meg ôket üdítôre, vagy sörre. A checcai oldalon lényegesebb kevesebb árus van, de itt is meg lehet kapni a melegételt, szénsavas üdítoóket, kokát, cigarettát, likốröket. A Mikayón csak sört, kenyeret és üdítőt árultak, ezeket úgy 2-3 asszony cipelte fel a kisboltjából. A Toctón 4-5 árus kínálta ugyanezt. Miközben folyik az evés-ivás, kokarágás, események kommentálása, egykét orvos a sebesülteket ápolja, kíváncsiskodókkal körbevéve.

\footnotetext{
${ }^{4}$ Belaúnde elnökségének elsô idôszakában (1963-1968) a hatóságok próbálták eltörölni a rítust, de nem tudták elérni céljukat.

Egy quehuei tanár jegyezte meg ezzel kapcsolatban: „a törvény nem elég ahhoz, hogy a szokásokat eltûntesse."
} 
4. Délután kettő és fél három között a feltöltôdött harcosok folyamatosan térnek vissza a küzdôtérre, hogy megkezdjék az utolsó félidôt.

A mérkôzésnek ez a félideje a machu akulli (a rágás közben kidudorodó kokára utal), vagy Picchu Tupac (Tupac hegy) már intenzívebb erôbedobással zajlik, hiszen el kell, hogy dóljön, melyik oldal gyôzedelmeskedik, kinek lesz dicsôsége és termékeny éve.

Küzdenek, védekeznek. Nem akarják, hogy az ellenség betegye földjükre a lábát.

Itt már kialakul a közelharc. A küzdelem döntetlennel is végzódhet. Ez azt jelenti, hogy egyenlố arányban hatoltak be a másik területére, kölcsönösen meghátráltatva az ellenfelet. Így történt 2005ben a Toctón és a Chiarajén is.

Az idôsebbek pásztázzák az eget, ôk még hiszik, hogy velük egy idôben a felhôk is küzdenek egymással, a villámokkal és mennydörgéssel pedig az Apuk, a hegyek szellemei játszanak és gyakorlatoznak, vélik. A felhốk meg tudják jósolni számukra, melyik fél fog gyôzzedelmeskedni.

A csapatok hôsiesen küzdenek egészen a második félidô végéig, ami sötétedésig tart.

Késô délutánra a fennsíkon az idô már sokkal hidegebb, elkezdôdik a jégesôzés, olykor havazás is, az ég beborul, villámok cikáznak. Az utóbbi összecsapásokról ezért társaimmal kénytelenek voltunk elôbb eljönni, ami több órás gyaloglást jelentett a jeges esôben. A helyi asszonyok, hajadonok, gyerekek viszont mind fönn maradtak a tomboló égbolt alatt, a természet erejére fittyet hányva izgultak tovább szeretteikért.

A csata végeztével a harcosok az ellenféllel közös egyetértésben visszatérnek a pihenóhelyre, onnan pedig elindulnak a falujukba. Másik lehetôség, hogy meneküléssel záródik a küzdelem. Így történt például a 2004-es Chiarajén, a checcaiak oldalán, ahol állítólag hazáig üldözték az ellenfelet. A küzdelem után gyakori, hogy a férfiak együtt folytatják az iszogatást a településeken. 
A rítusok utóéletét tekintve, ha haláleset van, a halottat vagy a helyszínen temetik, vagy elviszik és a falu temetôjében helyezik nyugalomba. Ha az ellenség elkap valakit a másik csoportból, a következố történhet: ruhadarabjait elkobozzák, és ütófegyverekkel agyonverik. Ha igen kapatos, erre nagyobb esélye van, hiszen nem képes menteni magát, azaz meggyôzni az ellenfelet, ne öljék meg. Az is mentôöv lehet, ha a jelenlévôk közül barátot, ismerôst fedez fel, aki ilyenkor védelmébe veheti, kimentve a fémvégú ütôfegyver csapásai elól. Az áldozatot persze így is helybenhagyják, de nem ölik meg, hanem fogolyként elhurcolják mint trófeát. Ilyenkor megszégyenítik: megverik, meztelenre vetkôztetik. A legnagyobb szégyenbe akkor hozzák, amikor nôi ruhát adnak rá, és így kell táncolnia a fötéren. Megölni nem lehet, mindenki tudja, hogy ez már nem a rítus helyszíne, ez már játékon kívüli terület, a hatóság közbeavatkozhat. Régebben dolgoztatták is a foglyot: kis kunyhóban tartották fogva a földeken, napközben pedig ásott, kapált, hiszen kénytelen volt együttmúködni. Enni-inni kap. Isznak a helyiek is, ráadásul mind a fogoly kontójára. Családja pár nap múlva kiválthatja: fizetniük kell mindent, amit a fogva tartók fogyasztottak. A régi szokások szerint asszonyokat is elrabolhatnak, és ha nincs férjnél, megesik, hogy fogva tartójánál marad végleg, családot alapítva.

Közvetlenül a küzdelem után, ha ellenségek találkoznak, sértegethetik, fenyegethetik a másikat, de már nem ütik meg egymást állítják az adatközlôk. A rítust követô napon az elôzố nap rivális felei között nincs harag, együtt kocsmáznak, piacoznak, vagy intézik közös ügyeiket. A csoportos ellenségeskedés csak arra a napra szólt, akkor is, ha valamelyikük térfelén haláleset történt.

A Mikayo rítus faluközösségek között zajlik. Kevés létszáma miatt a legkisebb, bevezető, egyfajta „felkészítô” küzdelem - állítják a helyiek.

K’atkani és Pongoña oldalával (K’ayno, Ccolliri, Quecha Quechából és Tupac Amaru körzetbôl- Ccotañából és Tungasucából néhány fiatallal szövetkezve), Yanaoca környezô földközösségei (Hanccollo, 
Hampatura, Chiqnayhua és a hozzá tartozó Puca Puca, Llallapara, Quellahuani, Jaquira Concából és egyesek Quehue körzetből) állnak szemben.

Még kevesebben mennek a Mikayo pampától húszpercnyi járásra fekvố Wawanake pampára ${ }^{5}$, a szombati játék elnevezésú küzdelemre, ahol csak fiatalok vesznek részt a szomszédos közösségekból. Ez már a karneváli idôszakot beharangozó rítus.

A Chiaraje (vagy Chiaraqhe, Chiyaraqe) jelentése: „fekete ember”, vagy más fordításban „a hely, ahol az alvadt vér képzódik”. Ez egy falvak közötti összecsapás, regionális szinten. Az alsó részrốl Quehue és a felsố részrốl Checca körzetének harcosai csapnak össze koalícióban szomszédos körzetek falvaival. Quehue faluja a hozzá tartozó közösségekkel (Qollana Qhewi, Hamp'atura, Shullunkani és Llallapara), Langui, Layo falvaival, míg Checca faluja és az Apurimac folyótól jobbra található közösségeivel (Ch’eqa Llaqta, Thuksa, Kunsa, Urqoqa, Intikancha, k'illawara, Sawsaya, Hanansaya és Qollana) és El Descanso körzetéból érkezett harcosokkal lép szövetségre. Nincs mindenki egy pihenốhelyen, három vagy négy dombon állomásoznak. Ez a rítus a helyiek szerint nemzeti szinten is elismert.

A küzdelem helyszíne 4500 és $4900 \mathrm{~m}$ tengerszint feletti magasságban a Chiaraje pampán (vagy másnéven Yuraq K’anchay pampa) fekszik, ami majd egyenlố távolságra van a két tartomány, Canas és Canchis között. Canas négy körzetének - Quehue, Checca, Yanaoca és Langui határai között terül el, a Chiaraje hegy fekete szikláinál, melyek a hófedte Gongonilla lábánál találhatók. A körülbelül két

\footnotetext{
${ }^{5}$ Fiatalt, gyereket jelent. A Mikayo pampától felfelé úgy negyed óra gyaloglással érhetô el.

${ }^{6}$ Erre példa Sicuani közelében a „Három királyok lóversenye”. Ha a szerecsen király álarca mögé bújt lovas érkezik be elôször a célba, úgy tartják, abban az évben jó lesz a munka, a termés, és gyarapodnak a jószágok.
} 
kilométer átmérōjú pampát az Orcocca ${ }^{7}$, Londoni $^{8}$ és Iscurani nevú hegyek veszik körül. Abraham Valencia Espinoza perui néprajzkutató így ír: „a színhely a Qhanqhawa síkság, ismertebb nevén Chiaraje Pata, azaz hely, amit úgy is hívnak, hogy Apu Gongonilla Pata, tehát Gongonilla védôisten helye." (Cama, 2003:68)

A Tocto rítus egy tartományok közötti küzdelem. Ez a legelzártabb a többi között, gyalog a kiépített úttól legalább négy-öt óra járást jelent. Nevének jelentése úr, üresség, de egyben hangutánzó szó is, ami robbanást, mennydörgést fejez ki.

Checca Apurimac folyótól balra esô közösségei Quehue egyes közösségeivel együtt immár egy oldalon harcolnak, egymást támogatva. Canas és Chumbivilcas tartománya között zajlik ez a küzdelem. Checcából Orqoqa, Chitibamba, Tandabamba, Shullunkiani, Consapata, Kuty Hanansaya, Tucsa Consa, Anansaya, míg Quehueból Winchiri, Chaupibamba és Ccollanaquehue közössége képviselteti magát és csap össze Chumbivilcas oldalról Liwitaca, Pisqaqocha, Sayta, Ausata, Q'echapampa és Ch'amaka harcosaival. A résztvevôk száma, megítélésem szerint, canasi oldalról kb. háromszáz fô lehetett a 2004-2005-ben. Ugyanekkor a Chiarajén összesen 600-700 ember gyúlt össze, míg a Mikayón maximum 150-200-an voltak jelen.

Az összecsapás idôpontjai:

december 8: Szeplötlen Szúz napja (Mikayo, Chiaraje, Tocto)

december 25: Karácsony napja (Tocto)

január 1: Újév (Chiaraje,Tocto)

január 20: Szent Sebestyén napja (Chiaraje, Tocto)

${ }^{7}$ Itt állomásozik Checca és az ôket segítô falvak.

${ }^{8}$ A két hegyet Quehue és szövetségesei foglalják el. 
február: „Komák” napja (mindig csütörtökön), egy héttel a karnevál elốtt (Chiaraje, Tocto)

február: "Szombati játék", egy nappal a karnevál elốtt (Wawanake)

Canas tartományon kívül máshol is elôfordulnak küzdelmi rítusok Peruban (pl. Ayacucho vagy Apurímac tartományban), ahogy más andoki ország, Bolívia vagy Ecuador területén is. Bolíviában a Tinku rítus ismert, ami „találkozást” jelent.

A világ más földmúvelésen alapuló társadalmainak harci játékain keresztül is megfigyelhetô, hogy azok szorosan összefüggenek a termékenység befolyásolásával, és gyakran nem elválaszthatóak a presztízs vagy területszerzés indítékától, mely minden esetben két fél oppozíciójából ered. A rituális küzdelmek jellegzetességeiket, sajátságaikat, kialakulásukat tekintve kulturálisan meghatározottak. Nagyban függenek a társadalom éthoszától és környezetétôl.

A társadalmilag gerjesztett erôszak a világ minden társadalmi szintjén, mindenféle formában megnyilvánul, legyen az világi vagy rituális küzdelem, tehát mindenképpen egy egyetemes emberi tulajdonság.

\section{A rítus eredetének hipotézisei}

Az andokbeli rituális verekedések eredeteként a következóket foglalhatjuk össze:

- preinka küzdelmek

- az Inka dualizmus

- aylluk ${ }^{9}$ közötti területi viszályok

\footnotetext{
${ }^{9}$ Inka földközösségek
} 
- kanas és qolla kisebbségek küzdelmei

- az inka fiatalok erópróbái: a Warachicuy

- II. Tupac Amaru gyakorlatozása

\section{A küzdelmek mintái a hódítás elôtti Peruban}

A rítusok történeti gyökereit vizsgálva már a prehispán idôkbôl vannak bizonyítékok rituális háborúkra. A preinka moche kultúrában (i. e. 300-i. sz. 800) egyes elméletek szerint fegyveres erôkkel tartották fenn birodalmuk határait - írja Topic (1997:10). Más szerzốk értelmezése szerint viszont a moche ikonográfia az egyes régészeti leleteken küzdelmi rítusoknak reprezentációi. Anne Marie Hocquenghem (1987:5.fej.) ${ }^{10}$ a küzdelem jeleneteit a moche kerámián mint tinku (rituális küzdelem) magyarázza. Szerinte a harc nem szabad formában, hanem párban zajlott. A harcosok viselete és fegyverzete jelzi, hogy mindannyian mochikák voltak, ami arra utal, hogy nem volt összecsapás különbözó népcsoportok között. A csaták fô oka a fogolyejtés volt, akiket késôbb feláldoztak. A vérnek náluk is jelentôs szerepe volt, akárcsak a tinku etnográfiai leírásaiban. A fogolyejtés a moche kultúra ôsmotívuma. Donnan (1978:182) ${ }^{11}$ felismerte, hogy a vér csak az egyik jelenet a láncról, mely a csatával és fogolyejtéssel veszi kezdetét. Shimada (1994:110) ${ }^{12}$ is elveti az ötletet, hogy a mochék csakis világi küzdelmeket folytattak, azaz csupán területi terjeszkedésból vagy védelemból küzdöttek volna. Szerinte az ikonográfiák rituális küzdelmeket mutatnak, akár a festett chimú textileken. Sốt, az is alátámasztja ezt, hogy egyes harcos szereplôket túldíszítetten ábrázolnak, tehát nagyobb a valószínúsége

\footnotetext{
${ }^{10}$ Idézi Topic 1997:11

${ }^{11}$ Idézi Topic 1997:11

${ }^{12}$ Idézi Topic 1997:II
} 
a rituális háborúra való utalásnak. A kérdés az: vajon a világi küzdelmek nem voltak ritualizáltak? ${ }^{13}$

Arkush (2005:5) megemlíti, hogy a moche és nazca tengerparti kulturák régészeti leleteinek ikonográfiájából olvasható ki legjobban, hogy a prekolumbián idôkben az Andokban erósen ritualizált háborúk mentek végbe. A vésett táblák építészeti kettôssége valószínúleg nem igazi háborút ábrázol, hanem két rész összekapcsolódásának társadalmi kettôsségét, ismételt rituális küzdelmekben. Más úgy értelmezi a faragványokat mint az újjászületés és halál kozmikus ciklusának strukturált reprezentációját (Kaulicke:1995) ${ }^{14}$.

Néhány tudós az inka háborúk rituális aspektusait hangsúlyozza: áldozatok bemutatása, a harc kimenetelének megjóslása, idolok, szent tárgyak harcba vitele, diadalmenetek, emberi trófeák, mindmind errốl tanúskodnak. Az Inkák az ellenség fejét lándzsára tûzve vitték a harc után: úgy tartották, a rivális varázserejét birtokba vették, vérének ivásával pedig elnyerték bátorságát. „A termékenységet növelő erôátvitel-képzet vezethetett sok esetben a fejvadászathoz" (Boglár 1995:47). A trófeák szerzése és a foglyok feláldozása egyébként nem ritka jelensége a premodern ${ }^{15}$, és modern társadalmaknak.

Az ecuadori ,juego de Pucarâ" összevetve hasonlít a tinkura és a moche reprezentációkra, ahol a férfi párok egymás haját húzzák, vagy a chimuknál, ahol egy kézzel húzzák a hajat és közben a másik

\footnotetext{
${ }^{13} \mathrm{Az}$ antropológusok általában megkülönböztetnek nyugati és nem nyugati, vallásos és világi háborúkat. Az aymara vagy kecsua nyelvben viszont nem létezett megkülönböztetés világi vagy rituális összecsapások között, mivel számukra a kettô együtt élt. ${ }^{14}$ Idézi Arkush 2005:5

${ }^{15}$ A mochéknál a foglyokat feláldozták, és bizonyos esetekben hagyták a tetemeiket megrohadni, megtagadva tôlük a temetést. Állítólag néhány esetben nemcsak trófeákká tették koponyáikat, hanem kibelezték és megcsonkították ôket. Az Inkák az ellenség gyomrából és bóréból dobot, lábszárcsontjából furulyákat, fogaiból nyakláncot készítettek. (Handbook of the South American Indians Volume 2, Washington, 1947:279)
} 
kézzel egy kôre támaszkodtak. Brownrigg (1972:97) ${ }^{16}$ említi, hogy régen a gyôzztes elvágta a halott vesztes torkát, hogy a vért elvethesse a földjein. Egyes nasca trófeáknál pedig párhuzamos vágást ejtettek a fejen, hogy elvezesse a vért. Tehát mindez bizonyíték is a vér elvesztése és a föld termékenységének kapcsolatáról, megerôsítve a rituális aspektust.

Hopkinsnál (1982) olvashatjuk, hogy gyarmati krónikák utalnak az 1772-es langui-i küzdelemre, amely három napon keresztül tartott a karneváli időszak alatt Hanansaya és Urinsaya között, tehát a felsố és alsó aylluk között. A korabeli hatóságok kövekkel és parittyákkal végzett bestiális játéknak vagy rossz szokásnak nevezték (Remy: 1991:264). A 18. században máshol is voltak hasonló küzdelmek Canas és Canchis tartományban ${ }^{17}$. Cobo krónikájában (1653:126127) ${ }^{18}$ ír egy Camay nevü (az Inkáknál a januárt nevezeték így) 15 napos csatáról, ahol az ünnep keretében összecsaptak. A küzdelem teliholdig tartott. Ezután Hanan és Hurincusco urainak mumifikált testét a téren a két fél határára helyezték, ahol ételt és italt áldoztak a számukra. Kétnapos ünnep, ének és tánc után mindenki elment a földjére, hogy megmúveljék a parlagot 12 nap alatt. Ez alatt az idô alatt a föld nedves és legalkalmasabb mezôgazdasági múvelésre.

Az aylluk (földközösségek) közötti versengés harci ünnepei alatt kemény gyümölcsöket hajigáltak egymásra parittyával, így halálos áldozat is volt. Ezek után az Inka véget vetett a küzdelemnek, és jöhetett az ünnepség és a mezógazdasági tevékenység kezdete ${ }^{19}$.

\footnotetext{
${ }^{16}$ Idézi: 1997:22

${ }^{17}$ A térség indián neveit 'Kanas és Kanchis', a gyarmatosítás elôtt itt elố két indián törzs neve után kapta. A kanas törzs - ahogy a krónikák mondják - melankolikus, de gôgös nép, kedvelték a sötét és fekete színeket, zenéjük szomorú volt és halk. A kanchis vidám szellemú, gondtalan nép, mely örökös viszályban élt a kanassal, akikkel csak az inka hódítás következtében kialakuló közös sors békítette ki. (Anderle 1981:180) ${ }^{18}$ Idézi Hopkins 1982:169

${ }^{19}$ Ezt az eseményt Cobo és Acosta krónikaírók is megemlítették.
} 
(Hopkins, 1982) Az Inkáknak legalább három alkalommal volt tinku típusú összecsapása: decemberben a warachicuy ceremónián (amikor a fiatal Inkák betöltötték a felnốtt státuszokat), az Inka királyok temetési rítusán és annak az emlékére, hogy Huayna Cápac Inka összecsapott az északi területrôl való katonákkal Saqsaywamanban.

Az inka háborúk közeli kapcsolatban álltak a természetfeletti hiedelmekkel. A eredményt determinálta az Inkák szent helyeinek ereje és az ellenségeinek gyengesége.

\section{A történelmi múlt}

Az általam megfigyelt területen élô kecsuák számára a prehispán rituális küzdelmek minden bizonnyal máig megteremtik a harcok kulturális mintáit. A harcok ideológiai, történeti alapját azonban már nem elsốsorban ezek, hanem a spanyol gyarmatosítókkal szemben a 18. században fellázadó II. Tupac Amaru háborúi szolgáltatják.

A forradalmár személye és tettei az andokbeli identitást erôsítik. Feltételezhetốen Amaru az inka warachikuy erôpróbáihoz nyúlt vissza. Már az Inkák idejében is próbáknak vetették alá a gyermekeket, hogy bizonyíthassák rátermettségüket és érettségüket. Ez egyfajta beavatási rítusnak felelt meg. A sok fiatal tehát lelkesen készülôdik az összecsapásra, ma is izgatottan várják az erôpróbát. „Szeretek a kớvel játszani. A focinál is izgalmasabb, mert van veszélye: a kövek elól menekülni kell. Olyan, mint a jégesố, süvöltenek, jobbról, balról, ezért ügyesnek és sebesnek kell lenni. Ha megfutamodsz, az ellenség inkább célba vesz" - avatott be a serdüló Alberto Mamani.

José Gabriel Condorcanqui, más néven II. Tupac Amaru az 1572ben fellázadt „utolsó Inka” Felipe Tupac Amaru örökségét és lázadó szellemét idézte.

A forradalom hốse Surimanában, Canas tartományban született 1738-ban, indián nemesi család sarjaként. Anderle (1996:178) 
szavaival „.. a gyarmatellenes függetlenségi háború elsó fejezetét is jelentette Latin-Amerikában". Nemzetegységesítő törekvés volt, egyesíteni akarta a kizsákmányolt embereket faji és osztálykülönbségektôl függetlenül, hogy szembeszálljanak a kizsákmányoló ellenséggel. 1780-ban a forradalmat „Szabadság és Igazság” felkiáltással bocsátotta útjára. A fốbírót foglyul ejtette és felakasztatta Tungasuca fơterén. Majd összetoborzott egy nagyszámú hadsereget. Fegyverzetük parittya és néhány puska volt, de így is gyôzelmet arattak Sangararában. A vesztes spanyolok fegyvereivel tért vissza Tungasucába, ahol indiáncsapatokat szervezett. Hasonló helyzetú falvakba is elvitte szavát és végül gyúrút vont Cusco köré. Számos összecsapás és szervezés után, 1781ben végül a spanyolok kerekedtek felül, és a kegyetlen Areche kínhalálra ítélte: lovakkal négyfelé tépette, és családját is kivégeztette. Feldarabolt testrészeit lándzsára tûzték: fejét Tintában, karjait Tungasucában és Carabayában, lábait Livitacában és Santa Rosában. Ezzel kezdetét vette az Andok területén a Tupac Amarukultusz.

II. Tupac Amaru fontos részét képezi az andesi emberek identitásának. Szobrai minden fôtéren emlékeztetnek rá és tetteire, utcák, sốt tartomány is nevében ôrzik emlékét. Az Inkák fô fegyverével, a parittyával és kövekkel gyakorlatozott verbuvált hadseregével, rögtönzött módon harcolva a spanyolok ellen. „A Chiaraje egy hegy, onnan viszünk le köveket,ezeket a köveket használjuk a harc közben. Tupac Amaru is használta embereivel, mert ott edzettek, pont azon a helyen volt a kiképzés" - mondta egy fiatal indián.

Espinoza írja, hogy a canasiak hasonló harcos attitúdjük miatt az Inkák szövetségesei lettek, akik tôlük tanulták el a fegyverkészítést (pl. parittya készítését, amit pásztorkodásnál használtak) és néhány harci stratégiát. Ezen a földön, ahol „megragadt” a harcos szellem, folytatja, a bátorság a mai napig az egyik legnagyobb erénynek számít.

German Zecenarro egyetemi tanár, történész, Cuscoban él. Beszélgetésünkben a canasi ember pszichéjét a történelmi múlttal 
kapcsolatban elemzi: „...A canas nemzet az Inka-kortól kezdve a mai Espinar és Canas tartományok földjén élt. Forrongó és harcos természet nyilvánul meg a szokásaikban, táncaikban és énekeikben. Eredetük centruma a mai Espinar volt, ahol hadgyakorlatokat végeztek, ezáltal jelentốs területet birtokoltak Arequipától Quiquijanáig egészen Canchisig. Ez egy nagy területen fekvố régió volt, Espinar központtal. Ide tartozott Quehue és Checca is, majd 1917-ben külön körzetekké váltak. A canasi emberekben a háborús szellem él tovább. Blas Valera is írja XVI. századi krónikájában, hogy az aylluk (földközösségek) egymás között gyakorlatoztak, hogy felkészültek legyenek a háborúra. Utána táncoltak, énekeltek; vagy említhetném Acostát is, aki 1590-ban jegyezte le, hogy látott Peruban egyfajta játékos küzdelmet, amiból aztán bandák háborúja robbant ki."

A Tocto hegyén egy harcos így beszélt: „Tocto volt az elsốküzdelem, késóbb alakult ki a Chiaraje és a Mikayo. A Toctón gyakorlatoztak, hogy csatlakozzanak Tupac Amaru seregéhez. Már az Inkák is itt gyakorlatoztak a hóditó háborúik elôtt. Így mesélték ôseink."

A 18. század elsố felének indián mozgalmaiban közös mozzanat a restaurációs szemlélet, vagyis az andoki utópia, az Inka Birodalom feltámasztásának gondolata. Egy nagyon érdekes elmélet szerint II. Tupac Amarut Inkarríval azonosítják a kecsua utópiában. A legenda szerint az üldözött Inkarrí az ôserdôbe menekült és ott él, hogy egy nap feltámassza és helyreállítsa a szegények közt a nagy Inka Birodalmat ${ }^{20}$. Sokak számára az indián forradalmár Inkarrí megtestesülése, és a közkedvelt mítosz Jézussal is sok hasonlóságot mutat. A jóslat úgy szól (mintha csak Juan Chocne jóslatának parafrázisa lenne), hogy II. Tupac Amarut, a karizmatikus vezetôt, aki harcolt az igazságtalanság és az indiánok kizsákmányolása ellen,

${ }^{20}$ „Garcilaso de la Vega Kommentárjaiból nôtt ki egyebek mellett az Incarrí mítosza, szerepe volt Tawantinsuyu idealizált képének újraélesztésében, egyes hagyományok és ôsi jelképek föléledésében..." - írja Carlos Ivan Degregori (Replika 29, 1998. március: 105-116) 
bár felnégyelték, feltámad majd egy nap, és tagjai egyesülnek Tawantinsuyuval együtt, hogy igazságot tegyenek. Krisztus feltámadása ez, az andoki utópia szavaival - állítja Estermann (1995:40).

A rítusok, harcok alkalmaival a kecsua indiánokban újra és újra megerôsödik a tudat, hogy ốk a szabadsághốs vérei, leszármazottai. A küzdelemben megmutatják, hogy nemcsak békés pásztorok vagy jámbor földmúvesek, hanem ha kell, megállják a helyüket a harcban is. A vér tehát nem válik vizzé. Hanem felforr.

A 2004-es Mikayón egy fiatal, népviseletbe öltözött indián fiú szerint a harc pillanatában feltör bennük, hogy ók II. Tupac Amaru vérei, örökösei, akiknek meg kell védeniük a földet, és le kell gyốzniük az ellenséget.

A következtetést levonva, a rítusok számos aspektusa között fontos tényezôt képez II. Tupac Amaru és a hozzá fưzốdô hốsiesség és szabadságfogalom. Az emberek húen ôrzik emlékezetükben, identitásuk és kulturális tudatuk meghatározó részévé vált. II. Tupac Amaru tulajdonképpen maga az utópia, maga a dicsố és követendô példa az andoki emberek számára, mely a rítusok alkalmával megelevenedik, testet ölt, csak a tényleges ellenség már nem a spanyol hadsereg, hanem a szomszédos falvakkal történik a rivalizálás. Továbbá a különbözó értelmezések egyik rétegeként úgy is meg lehet ragadni a küzdelmet, hogy ideológiai kifejezôdése egy társadalmi helyzetnek vagy etnikai tudatnak. Identitáskonstrukciók rituális kifejezôdése, amelyek történelmi eseményekhez nyúlnak vissza. Ennek a megteremtésében ugyanúgy szerepet játszhat az orális hagyomány, a kollektív emlékezet, mint a helyi értelmiségiek identitásteremtési kísérletei. 


\section{A harci rítus mint termékenységi áldozat}

Amikor a spanyol hódítók és a gyarmatosítók hittérítôi elterjesztették a kereszténységet Dél-Amerikában, az ott élố ôshonos indiánokra egy új Isten és szentek imádását kényszerítették rá. Az Inka uralom alatt a nép vallása a politeizmusra, az animizmusra és az ôsi totemizmusra épült. A két vallás találkozása az Andokban szinkretizmust eredményezett. A kereszténység elemei adaptálódtak az andoki hitvilág elemeihez és fordítva. Peruban a legerôsebb keresztény vallás a katolikus.

„A rituális küzdelmek napjai egybeesnek a katolikus ünnepek napjaival, és jól mutatják a keresztény és animista hit szinkronizmusát." (Anderle 1981:102) A december 8-ai rítus a termékenység napján zajlik, mely egyben a Szeplốtlen Szúz termékenységének napja is. December 25-e karácsony napja, a ,gyermek játéka”, de ezen nem vesznek részt sokan, a legtöbben otthon maradnak családjukkal. Január elseje az „újévi küzdelem”, egy újabb év, egy újabb ciklus kezdete. Január 20-a Szent Sebestyénnek (aki Cusco város egyik kerületének védốszentje; i. sz. 288-ban nemes és bátor katonaként szenvedett mártírhalált) napja, az ô tiszteletére játsszák ezen a napon a küzdelmet. Február, egy héttel a karnevál elôtt: a „karneváli játék, találkozás", ebben az idôszakban zajlanak az állatszaporító rítusok is.

Az indiánok közül sokan a templomba járnak imádkozni a szentekhez, miközben otthon a Földanyának áldoznak. A rítusok számukra jó alkalom arra, hogy a keresztény szentek vagy andoki istenek megbüntessék ốket, ha vétkesek, vagy megbocsássák bứneiket. Ítélhetnek felettük.

A rítus egyik fontos eleme a Földanyának (Pachamama) szánt áldozat, a „pago a la tierra”. A „pago”, tehát a szellemeknek szánt fizetség, kiengesztelố rituális cselekedet. A csata elôtt kérik, segítse óket a küzdelemben, és hátráltassa az ellenséget. Az áldozati csomag égeté- 
sét, vagy fohászkodást a hegyek szellemeihez az indiánok ôsidôk óta végzik. Kiengesztelik a felsốbb hatalmakat, ezáltal a biztosítják a harmóniát ember és természet között.

Az áldozati láma (vagy birka) kifolyó vére és kitépett dobogó szíve szintén fizetség, melyet a földbe helyeznek, hogy egyesüljön a Földanyával. A szív, mint a legértékesebb és életet adó szerv, a termékenységet szolgálja, abban az erốs hitükben, hogy ezáltal szaporodnak az állataik. Az indiánok világnézete szerint ${ }^{21}$ a Földanya él, egy éló szervezet, akinek hatalma van. Olyan, akár egy anya, aki táplálja és felneveli gyermekeit. Ezért tiszteletet érdemel. Mítoszok is kötốdnek hozzá. Pachamama megszemélyesített lelke, kultikus lénye a földnek, ố az, aki kontrollálja a termékenységet növényben és állatban. Kétszer nyílik meg egy évben: februárban és augusztusban. „Ez alatt az idó alatt szomjas, felbốszitett, élố és nyitott” - mondja Mariscotti (Hopkins 1982). Másrészt „a lábasjószágok terhét viselik, és bizonyos társadalmi kontroll funkciót hajtanak végre" (Earls 1969:67)22. Míg a földmûvesek a Földanyával, addig a pásztorok az Apukkal állnak közelebbi pszichikai viszonyban, mivel ôk közelebb élnek a hegycsúcsokhoz.

Az indiánoknak, akiknek élete függ tôle, ki kell óket engesztelniük, hogy jó legyen a termés. Sốt, sokszor attól is megbetegedhetnek, hogy nem végezték el idôben a felajánlást. Tehát közvetlenül az emberekre is hat. Mindennaposak a kisebb rituális cselekvések, pl. az elsố szomjoltó korty felajánlása. Az állatokat, mielôtt levágják óket, szintén folyadékkal hintik meg, hogy a lelkük ne dühödjön meg.

\footnotetext{
${ }^{21}$ Az inkák három részre osztották fel a világot: Hanan Pacha az ég, ami a felsố világot jelenti, azok térnek meg oda, akik az erényeik miatt elnyerik jutalmukat. A mi világunkat alsó világnak, Hurin Pachának hívták, a nemzedékek és korrupciók világának, a legalsó világot a föld közepében pedig Ucu Pachának, ahová a rosszak térnek meg. (Estermann 1998:176-177) Idézi Brachetti 2001:70.

${ }^{22}$ Idézi: Gose 1986: 299
} 
Biztosítják a Földanyát emlékezetükrôl, megtesznek mindent, nehogy a hegyek szellemeivel (az Apukkal) együtt magukra haragítsák ôket. Elég egyszer elmulasztani az imádságokat, vagy szomjazni hagyni Pachamamát, a Földanyát, a következmények mindig negatívak: a termést tönkreteheti a jégesô, éhínség lesz, vagy állatok pusztulnak el.

A kecsua nyelvú indiánok számára a földdel való kapcsolat a spanyolok elốtti idốk óta szent, hiszen a föld adhat is, de el is vehet. A rituálék a reciprocitást követve a tiszteletet és megbecsülést fejezik ki, így igyekeznek az emberek és a természet között harmóniát biztosítani, és fenntartani a kozmikus rendet. Ezek a cselekedetek ápolják a földdel az intim és kölcsönösségen alapuló kapcsolatot, melyek az andoki indiánok továbbra is élố animista hitvilágát, világfelfogását fejezik ki. Rituálisan egyszerre három kokalevelet több irányba megfújva, halk fohászt mormolnak a megnevezett szent hegyek felé, így teremtenek közvetlen kontaktust. Ilyenkor belépnek egy szakrális dimenzióba, a hegyek szellemei pedig meghallgatják ôket.

A rítuson a halott vagy sebesült vére mintegy „vetômag”, mely az újjászületést célozza meg, a termékenység szimbóluma, és annak jele, hogy a Földanyának szüksége volt az áldozatra, és elfogadta a felajánlást. A halál az áldozat szimbóluma. „Ha gyoóztetek, és még halott is van, még elégedettebben távoztok." Ezért nincs sírás és vádaskodás. Ha vér folyik, az kedvezó elôjel az indiánok szerint, jó évet jelent mindenkinek: „az állatok szaporodásának és védelmének, a termésnek, a családnak, a falunak és a tartománynak.”

Akárcsak a preinka és inka kultúrában, a közép-amerikai aztékoknál is fontos volt a vér (ezen belül az emberáldozat és állatáldozat), mely vallásuk szerves részét képezte. Ünnepekkor a harcok közben ejtett foglyok torkát vágták el és szívét tépték ki, felajánlva az isteneknek. Különbözố tudományos hipotézisek megkérdôjelezik, hogy az Inkáknál volt-e emberáldozat. Én azt gondolom, hogy egy ilyen archaikus civilizációban a vérnek tulajdonított mitikus ôserô, maga, mint életnedv, és az istenek tisztelete közötti szoros kötelék miatt 
erôsen feltételezhetô az élő emberek áldozata is, akiket különleges eseményekkor vagy súlyos válság idején áldoztak fel, de az aztékoktól eltérôen jellemzôen inkább állatáldozatokat végeztek.

A halált az élet folytatásnak tekintik, ami egy harmonikus életet biztosít. „Az új életben nincs fáradtság, és mindenki dolgozik. Pacha nem csak földet jelent, hanem teret, szintet, idôt. A kecsua ember nem ismer jövố idôt, a jelen idôt használja. Az idô mint az örök jelen állapota, periodikus ismétlódés: akár a mezógazdasági munkák ciklusai, napszakok vagy a száraz és esôs idószak váltakozása. Náluk inkább a múltnak van jelentôsége a jövóhöz képest, ebben gyökerezik retrospektív utópiájuk is." (Miranda 1996:123) Az indiánok számára az egész univerzum szent, mert mindegyik része az isteni rend része a viszonyok rendszerében. A kecsua földmúves magába fogadja és tartalmazza a „mást” és az „újat” anélkül, hogy bomlasztaná világnézetének alapstruktúráját. Így adaptálta át a keresztény vallás elemeit is. A katolikus keresztet az andokiak a chakana jellel állítják párhuzamba, aminek végzôdései a négy égtáj felé mutatnak, és hidat szimbolizálnak a kozmikus terek között, fent és a lent, jobb és bal, mikro- és makrokozmosz kapcsolatára, a föld és az ég viszonyára utal. A katolikus isteneket hamar „andesítették”, párba állították a saját istenségeikkel, akárcsak a szenteket a természeti jelenségekkel - írja Estermann. (1995:39).

Mivel a fennsíkokon az emberek főfoglalkozása a pásztorkodás, állattartás, ezért a rituális gyakorlatok nagyban kötődnek az állatállományhoz is. Az indiánoknak különbözô szaporodást elôsegítô ünnepeik vannak, pl. a ch’allakuy, az állatok összeházasítása ${ }^{23}$. Az állatok

\footnotetext{
${ }^{23}$ Kiválasztanak egy nôstény és egy hím fiatal juhot. Egy andoki szertartásvezetô celebrálja az „esküvôt”, az állatok füleinek vérét egyesítve. Befestik hosszanti csíkokban vörös színnel a két juh fejét. A pap levág egy kis darabot az egyik juh fülébôl, hogy gazdájuk megốrizze azt táskájában, mint amulett szolgál a termékenységhez. Végül az összegyúltek vidám táncot járnak.
} 
termékenységével kezdetét veszi a fiatalok közötti szexuális játék is. Különbözô játékokban és táncokban kétértelmú célzásokat tesznek az állatok közösülési mozdulatain keresztül, vagy az alvó lányokat pálinkával hintik, hogy jövoore az alpakák sokat fialjanak. Azaz párhuzamot vonnak az állatok termékenysége és az emberek termékenysége között.

A föld termékenysége és az állatszaporítás mellett tehát fontos a társadalmi reprodukció is, ezt szimbolizálja a fiatalok rítus alatti ${ }^{24}$, és karneválokon történó ismerkedése, és az azt követô pásztorórák.

A rítus elemzése szempontjából is nagyon fontos tény, hogy az andokbeli dualizmuson alapuló világnézetben a világegyetem két félre oszlott: alsó és felsô világra.

„Az Inka Birodalomban a városokat két részre osztották - egyeseket a király (felsô rész), másokat a királyné (alsó rész) emlékére -, hogy ezek egymásnak egyenlö testvérei legyenek, egymást kiegészítsék. Ehhez hasonlóan ugyanez a felosztás vol, kerületek vagy származás szerint: Hanan Ayllu és Hunin Ayllu magas és alacsony származást, Hanan Suyu és Hurin Suyu felsó és alsó kerületet jelentett. Innen ered az alacsonyan és magasan fekvố közösségek közötti összecsapás”- írja Garcilaso de la Vega a 17. században megjelent krónikájában $(1964: 41)^{25}$.

„Az andokbeli kozmovizió egyik kulcseleme és alapja tehát a dualizmusírja Letenyei -, a harc a világegyetem két fele, vagyis az Alvilág és a Felsó világ között. Az Alvilág, (aymarául Manqha, kecsuául Hurin suyu) a nóknek, termékenységnek, sötétségnek, nedvességnek, a Holdnak, a Felsö

\footnotetext{
${ }^{24}$ Elôfordul, hogy a fiatalok már hetekkel a rítus elốtt megtetszenek egymásnak, ilyenkor a rítus alkalom a szerelmes találkozásra is.

${ }^{25}$ Matienzo (1567:VI/20-21) kihangsúlyozza, hogy hanansaya felette áll hurinsayának, ami egy aszimmetrikus kapcsolatot mutat, de a rituális harcok alatt a két fél szimmetrikus viszonyban van. Tehát, habár a két fél eredendôen egyenlôtlen, a küzdelmek alatt egyenlôséget mutat. (Idézi Hopkins 1982:169)
} 
világ (Alaxa, illetve Hanan suyu) a Napnak, tüznek, szárazságnak, fényességek, férfiaknak világa volt. A két fél sohasem egyesülhet. Örök ellentét áll közöttük, mint a tüz és víz között, az örök vonzalom, mint férfi és nó között. Két indián közösség egymást aszerint azonosítja az alsó vagy felsô világgal, hogy egy falu alsó vagy felsó végében, alacsonyabban vagy magasabban laknak-e. Ellentétes princípiumokhoz tartozó csoportoknak meg kell küzdeniük. A két világ összecsapásának tere a rituális küzdelem. A tél magyarázata szerint például azért egyre hosszabbak az éjszakák, mert a sötétség erói megnövekedtek, ami ellen fel kell venni a harcot. A rituális harc közben kiömlö vér állítja helyre a megbillent egyensúlyt, és megtermékenyíti a földet." (Gelencsér, Letenyei és Takács 1994:28). A két világ állandó harca jelen van a mindennapi élet legkisebb dolgaiban is: az évszakok változása, vagy a nappalok és éjszakák változása mind-mind ennek az állandó küzdelemnek az eredménye.

Elképzelhetô, hogy ez a kibékíthetetlenség egyrészt a származásukból (király-királynő, felsô és alsó rész), másrészt abból adódott, hogy eltérô gazdasági tevékenységet folytattak a földmúvesek és állattartók.

A küzdelmek közvetlenül aratás elôtt zajlanak, az esôs idôszakban, decembertôl februárig. Ezt az idôszakot márciusig „a nagy érés” idôszakának nevezik. Néhány fennsíki növény is elkezd virágozni . A Földanya ilyenkor a legtermékenyebb. Az időjárás magas kockázati tényezô, rengeteg lehet a jégesố és erôs a fagy. Leginkább ilyenkor kell vigyázni a gazdának a vetésre és az állatokra. Ebben az évszakban ezért a leggyakoribbak a termékenységi ünnepek, felajánlások, hogy minél inkább biztosítsák a jó termést, évet, és ezért zajlanak ilyenkor a rituális harcok is. 


\section{Közösségépítő szerep}

A rítus, mint egy társadalmon belüli interakció, egy közösségi esemény, „magát az összetartozást, magát a közösségi eszmét fejezi ki [...] Az egyén és a közösség érdeke találkozik, fonódik össze ezekben. Az individuumok lényegében alá vannak vetve annak a csoportnak, amelyhez tartoznak, de a csoport tagjainak érdekei között hasonlóság áll fenn és ez nyújtja a szociális jellegét és értékét mind a csoportnak, mind a csoport tagjai által végrehajtott cselekedeteknek, szokásoknak” (Ujváry 1981:88). Durkheim (1912) és Radcliffe-Brown (1952) a rítust szintén kohéziós erônek fogta fel, olyan erônek, „, amely elösegíti a társadalmi integrációt és megszilárdítja a kollektív érzést"26.

A harci rítusok egyszerre a rivalizálás és egyszerre az együttmúködés kifejezése és folyamatos tudatosítása, melyek fontos jellemzôi az andoki társadalom ideológiájának.

Másrészt az andoki küzdelmek rituális jelentésében a szaporítási és egyensúlyi mechanizmus jelenik meg két fél szembenállásán keresztül, mely alapvetô szerepet játszik a helyi emberek, leginkább pedig a földközösségekben éló kecsua indiánok életében.

A termékenységi rítusok visszavezetnek az Andok kulturális gyökereihez, ezáltal erôsítik a közösségek tagjai közt a társadalmi kötelékeket és a kulturális tudatot. A rituáléknál felhasznált mágia mint szimbólumok együttese múködik. Egyfajta iránytúként funkcionál az indiánok számára, hogy eligazodjanak az ismeretlen transzcendens világban. Másrészt a rituálék optimistábbá teszik az indiánokat az idôjárás változásai és kiszámíthatatlan viszonyai közepette. Egyfajta egés zséges bizalom a jószerencsében elúzi az ebból fakadó szorongást, és serkenti a küzdô és ellenálló képességet, meg a harci kedvet.

${ }^{26}$ Idézi Boglár 1995/4:42 
Ami más termékenységi rítusoknál áldozati csomagok égetése és egyéb rituálék, addig a harci rítusokon a vér és a halálos ál dozatok a felajánlás, a fizetség a Földanyának. Az ôsi világnézet és gondolkodás a gyakorlatban élô szokásokban, rituális cselekedetekben nyilvánul meg és él tovább. Ennek közvetítôi a harci rítusok is. „A rítus: vallás akcióban"27; az áldozati csomagok égetésén és egyéb rituálékon kívül a harci rítusokon a vér és a halálos áldozatok szintén fizetség a Földanyának. „A véres harci rítusok alatt a halál-fogalmaz Barrionuevo - a közösségek közötti konszenzusban elveszti groteszk álarcát, hogy egy rituális áldozattá változzon." (1971:79)

A rítusok által kifejezôdik az is, hogy a föld termékenysége szorosan kötôdik az emberi termékenységhez. Ami - a földanya mágikus vallási kultuszán belül - egy olyan jelentést kap, hogy a két szembenálló fél szimbolikus egyesülése alatt kifolyt áldozatok vére beszivárogva a föld kérgei alá, megtermékenyítsék azt, és ezzel párhuzamosan kedvezzen a társadalmi gyarapodásnak, éppúgy, mint az állatállomány szaporulatának. Lényeg a bôség és mindennek újjászületése és megteremtôdése, maga az Élet. Ehhez kérik a Földanya és a hegyek szellemeinek együttmúködését, tudatában a kölcsönösségre épült kapcsolatnak.

\section{Harc és játék}

Minden harci rítus egyben egy kollektív játék is. Az Andok fennsíkjain végzett intenzív mezôgazdasági munka szüneteltével a helyieknek alkalmuk nyílik egy kis kikapcsolódásra a közösségük és a szomszéd közösség tagjaival. Ezzel egy idôben játékuk kiengeszteli a Földanyát is. A harc közben levezetik az agressziójukat is. A játékban részt vevô rivális felekkel a következô napon már békés a viszony,

27 Havilandot (1975:342) idézi Boglár (1995:41) 
visszaáll minden a régi kerékvágásba. „Másnap már barátok vagyunk, testvéremnek szólitjuk egymást, és együtt piacozunk."

A versengés és harc tehát csak arra a napra szól, a küzdelmet csak a meghatározott napon játsszák. A rituális összecsapásnál számít a gyốzelem, de nem ez az elsô, mint egy valódi háborúnál. A legfontosabb a közös részvétel, ingerek, a közösen átélt esemény, és minthogy ez egy közösségi erófeszítés, a cél is közös: mindenkinek jó éve legyen. Így erôsítik a kötelékeket társadalmon belül, miközben egy pár órára felszabadulnak a mindennapok terhei, gondjai alól. Tehát nem is annyira a gyôzelem náluk a lényeg, hanem inkább a játék, az izgalom, ami kiemeli, kizökkenti ôket az egyhangúságból, a hétköznapi élet monotóniájából.

Nemcsak az indiánok, de a velük egy közösségben harcoló meszticek számára is egyfajta szórakozás a harc. Számukra azonban nincs nagy jelentősége az Andokban élô hiedelmeknek, és vallásnak. Segítenek a föld védelmében, megmutatják bátorságukat, amivel biztosítják és növelik presztízsüket. Sokan csak sportból mennek, kihívásnak tekintik a küzdelmet, vagy nézókból válnak alkalmi harcosokká. „Menjünk játszani”, szól a buzdítás a rítus napján, vagy: „Jó játék volt”, hangzik el összegzésként. A játékosok nem dramatizálják a küzdelmet, teljesen természetesnek veszik a részvételt, és azt, hogy vért adnak a Földanyának. A játék szabályai szerint nincs igazságszolgáltatás, nem vádolják egymást a felek a halálos áldozatokért ${ }^{28}$. Hiszen mindez egy játék következménye, amelyben mindenki önként vállalja a részvételt.

${ }^{28}$ Egy 1772-es dokumentum szerint az egyik áldozat apja nemcsak hogy nem jelentette fel a gyilkost, hanem még közbenjárt érte a börtönben. (Remy, Los discursos sobre la violencia en los Andes. Cusco, CBC, 1991) 


\section{A résztvevók és a távolmaradottak motivációi}

\section{A rítuson jelen lévoók, de részt nem vevôk motivációi}

Tapasztalataim szerint a részt nem vevô jelenlévôk motivációi többnyire az alábbiak:

- kereskedés,

- megfigyelés-kíváncsiság,

- szolidaritás: ösztönzés, lelki támogatás,

- védelem-kíséret,

- baráti kapcsolatok ápolása,

- antropológiai kutatás, filmezés vagy rádióinterjúk készítése.

A harcra nem mindenki vállalkozik, vagy tudja vállalni a részvételt. Ezeknek okai lehetnek:

- a küzdelem durvaságának elutasítása („barbár szokás”- mondják fóleg a meszticek közül),

- félelem a haláltól, sebesüléstôl,

- újkeresztény protestáns kisegyházak vallási szigora, tiltása,

- öregség (bár ez nem mindenkit akadályoz, csak az igazán aggokat),

- rossz álom mint negatív jóslat,

- testi korlátozás (például amputáció),

- munka, távollét,

- ha valaki túl részeg (visszatartják a további küzdelemtól),

- azok az asszonyok általában nem mennek, akiknek nincs kit elkísérniük. 


\section{A motivációk összegzése}

A rituális küzdelmek okait, a résztvevốk motivációit mint a rituális ismétlôdés hajtóerejét, a következóképpen összegzem:

- vallási okok (istenek, fóként a Földanya kiengesztelése, a kozmikus rend fenntartása),

- gazdasági okok (termékenység, azaz bố termés, állatállomány, közösségi jólét),

- a történeti identitás megốrzése (ốk a lázadó szabadsághôs II. Tupac Amaru örökösei),

- szociális okok: közösségi kohézió erôsítése (a rítus, mint közösségi élmény, közösségi összefogás a közösségen belül és közösségek között),

- baráti kapcsolatok ápolása,

- szórakozás, kikapcsolódás (monotónia feloldása, játékösztön, sport),

- presztízs (a bátorság, férfiasság mutatása, a gyáva jelzố elkerülése),

- földjük védelme és határátlépés, avagy a közösségek közötti rivalizálás (és a gyốzelemmel járó dicsôség),

- ôseik iránti tisztelet (a tradíció ápolása),

- feszültség és agresszió levezetése.

Az elemzett harci rítusok számos, egymástól eltérô jelentésréteget súrítenek magukba. Akik hisznek a rítus termékenységet adó erejében, azoknak valóban rítus az összecsapás. Azok, akik pusztán szórakozásból vagy kíváncsiságból mennek, leginkább a meszticek. Mint egy sporteseményen, jól akarják magukat érezni, kiállva a bátorságpróbát és presztízst növelni, vagy erốt fitogtatni a társaik között. Számukra nincs nagy jelentôsége az Andokban élố vallási képzeteknek. Segítenek a föld védelmében, de sokan csak nézókbốl vál- 
nak alkalmi harcosokká. Egy mesztic férfi mondta egyszer: „Az indiánoknak más a gondolkodása, ók még hisznek a földben, istenekben, mi csak védelmezni megyünk, támogatjuk óket, mert nekünk vannak a legjobb lovaink”, vagy: „ók azt hiszik, hogy jó év lesz, én csak a játék miatt megyek”. Azonban az indiánok is azt mondják, ez egy játék. Számukra azonban több mondanivalót és szimbólumot hordoz. Játék, mert egy különleges állapot, arra a napra ellenfelekké lesznek az ismerôsök, vagy rokonok. Egy izgalmas csatában találkoznak, versengenek, miközben egy közös élményt élnek át, a társadalmi kontroll részvételével. „..oók még az isteneikhez fohászkodnak és hívják a Napot a gyơzelemnél' - mondta Martin Romero professzor Sicuaniban. A meszticek a Chiaraje rítuson vesznek részt leginkább, nem kevéssé befolyásolva azt, a Tocto és Mikayo viszont aránylag izolált, távolabb esnek a központi településektôl, oda föleg csak az indián földközösségek tagjai mennek.

A Chiaraje is jellegzetesen indián rítus volt, míg évrôl évre meg nem jelentek a mesztic résztvevôk és a turisták. A rítusoknak volt és van egyfajta nemzetpolitikai színezete is, egy komplex viszonyban az 1920-as és '30-as indiánfelkelésekkel, melyek többek között azt az igényt fejezték ki, hogy maguk felügyelhessék a földjeiket és a munkát. Ugyanis az indián elöljárók a nemzeti kormány rendeletéból megbízott mesztic származású elöljárók elnyomásától szenvedtek. A rítusok alkalmával az indián közösségek egyúttal autonómiájukat is kifejezik az uralkodó mesztic társadalmi réteggel szemben.

A jelenlévốk mindegyike tisztában van a rítus vallási képzeteivel. Az Andokban sokan követik a hagyományokat, jólétük érdekében gyakorolják az isteneket kiengesztelô mágikus rítusokat, áldozati felajánlásokat. Ahol sok a veszélyességi faktor, ott bizonytalanság van, ezért akár bármely más kezdetleges földmúves társadalomban, folyamatosan biztonságot és jó eredményt kívánnak elérni, a rítusok által „valami feszülő megoldhatatlanság enyhül”29.

${ }^{29}$ Marótot idézi Boglár (1995/4:40) 
A harci rítusok színterein egytôl egyig azt állítják, hogy a bôséges évért küzdenek. Így ôrzik kulturális értékeiket. Az indián faluközösségek társadalmi életében a rítus szimbolikus üzenetek hordozója. Ugyanis, mint kulturális örökség, az Inkák idejébe nyúlik vissza, ezáltal ôsi értékeket képvisel. A rítus egyet jelent a múlttal, hagyománnyal. A rítus újbóli átélése annak, hogy „honnan jöttünk, kik vagyunk”. A közösség identitását fejezi ki. Másrészt játék azokkal a falvakkal is, amelyekkel közeli a viszony. Felbomlik ilyenkor a társadalmi rendszer és hierarchia, mindenki egyként, testvérként harcol.

Gyakran a pszichikai befolyás és a szolidaritás vágya azokat is behajtja a küzdelembe, akiknek elsôdleges szándéka a megfigyelés volt. „A harcba lépés pillanatában nem érzel félelmet, csak keserüséget [...] amikor itt vagy a csata helyén, átjár, hogy ehhez a közösséghez tartozol, csak azt érzed, hogy valami lök belülról, és azt mondja: menj be" - mondta egy serdülô indián a Mikayón, aki már évek óta részt vesz a küzdelemben.

„Ezen a napon nem dolgozunk a földeken, hanem közösen megyünk küzdeni, társadalmi osztályok nélkül' - mondta a házigazdám, Manuel Sanomami Pongoñában. Elisvan Bravo quehuei tanító szerint a rítus erôsíti a kulturális identitást, amiból a gyerekek is sokat tanulhatnak, hiszen ötvözi a szokást, táncokat, viseletet, hitvilágot. „Nem arról van szó, hogy brutálisan összecsapunk és ennyi. Ez nem csupán vadság, ez egy természetes ösztöne az embernek. Nem vagyunk vadak, az indiánokkal együtt egy szervezett közösség részét képezzük. [...] A Chiarajét nem tudják megszüntetni, mert gyerekkorunk óta részt veszünk. Ha az 5 éves gyereket megkérdezed, mi az a Chiaraje, azt fogja mondani: a papácska, mamácska, testvérek oda mennek harcolni. Az iskolákban is tudják, mi az a Chiaraje. Mint egy játék, mint a foci, két csapat játssza, és játszani is fogja, és nem lehet megszüntetni” - füzi hozzá.

Bravo házában fia, a hétéves Juan büszkén mesélte, mennyire várja már a küzdelmet, tavaly is apja mögött ült a lovon. Elisvan, bár félti gyerekét, azt mondja, nem tilthatja meg neki, hogy vele 
tartson. Annak idején ô is követte apját, így száll ez a hagyomány apáról fiúra. Másrészt „a gyerek már most kiveheti részét a bátorságból” tette hozzá apai büszkeséggel.

Ezek az alkalmak továbbá távolabb éló rokonok, barátok, ismerôsök rendszeres találkozási pontjai. Sokan messzi városokból térnek vissza, hogy egy jót játsszanak, ezáltal ápolják a hagyományt, és egyúttal megvédelmezik közösségük területét. „Ügyvéd vagyok, de részt kell vennem és védelmeznem a közösségemet" - mondta egy Sicuaniban éló quehuei.

A küzdô felek ugyanakkor harcias szellemüknek adnak teret: a küzdelem pszichésen olyan hatással van a résztvevókre, olyan méretú agresszió gyülemlik fel az összecsapásban, hogy ez szinte tel jesen elvakítja óket. Ennek fokozódásában közrejátszik a folyamatos alkoholfogyasztás is, ami segít, hogy feloldódjanak a harcosok gátlásai. Bátorságot öntenek magukba. Igy lehetséges, hogy erôszakot tudnak gyakorolni - legfôképpen a közelharcra értendô - azokon, akikkel egyébként békés faluszomszédságban élnek.

Az évben csak a küzdelmek idején uralkodik háborús légkör a felek között, nincs bosszú, megtorlás, utána mindenki újra testvérnek tekinti egymást. Többször felhozták a beszélgetések alatt, hogy tulajdonképpen a harc alatt kiadják magukból, levezetik az egész évben felgyülemlett feszültségüket.

A harci rítusok - Appadurai szavaival - a lokalitás tér- és idóbeli termelésének a feljegyzései (Appadurai 2001). Arra utalnak, hogy az ott élók nem tekintik és nem is tekinthetik adottnak magát a lokalitást. Az csupán átmeneti jellegú marad, ha idôrôl idôre nem „termelik” újra, melynek egyik módja e rítusok idôról idôre való megismétlése és a bennük való részvétel. Hasonlóképpen, e rítusok nemcsak a lokalitásnak mint az érzelmek struktúrájának, hanem a térbeli szomszédságok megteremtésének, kontextualizálásának is visszatérố alkalmai. Lehetôséget ad arra, hogy az egymás mellett élő közösségek ekkor szimbolikusan újrafogalmazzák azokat a szabályokat, értékeket, amelyek szerint az egymáshoz való, rivalizá- 
láson és együttmúködésen alapuló viszonyukat elképzelik. Szimbolikusan újra kijelölik a falvakhoz tartozó termóföldek határait, miközben visszautalnak egy közös történelmi múltra is.

A küzdelmek alapvetôen a területi harcok emlékét frissítik fel, ami az ôsi inka világnézettel és vallással összekapcsolódva ri tuális jelleget kapott. A területek szimbolikus elnyerését az ellenféltốl a határátlépés mozzanata órizte meg.

A Chiaraje, Mikayo, Tocto egyszerre háborús küzdelem, játék, és rituális cselekedet. A földdel való kapcsolat a mai napig nagyon szoros, köszönhetốen annak is, hogy termelési módjuk és termelôeszközeik hagyományosak, nem váltotta fel gépi technológia. Viszont a modernizáció terjedése, a városi migráció mind-mind befolyásolják a fiatalok tudását, pszichéjét és ez generálja a változásokat is.

Egy indiai filozófus, Osho azt mondja, hogy a Nyugat természetes állapota a háborúzás és mikor nincsen háború, mondjuk úgy, béke van, valójában akkor is a háborúra készülnek fel. Nyugat-Európa legalább olyan erôszakos, mint bármilyen más emberi társadalom, a kolonializmus miatt talán a legerốszakosabb. A 14. századtól rövid idố alatti mészárlásnak tömegek estek áldozatul Afrikában, Ázsiában, Óceániában, Amerikában. Sốt, napjainkban is globális méretû az erôszak, az emberáldozatok száma.

Én úgy vélem, ezen is érdemes elgondolkozni, mielôtt véleményt alkotnánk más erôszakos jelenségekrôl, legyen az akár egy rituális háború. A nyugatiak természetesen vadnak, barbárnak titulálják az efféle kulturális szokást. A Cuscóban élố Zecenarro perui történész szerint „a rituális harc viszont a canasi emberek számára pszichéjük természetes megnyilvánulása. Számukra ez normális, ezért nem valami rossznak fogják fel. Ezzel a cselekedettel a földnek is tisztelegnek. Köszönet mondanak a Napnak, az Inkák istenének. Vérükkel adnak hálát a Földanyának. Így örvendenek. Életet, újjászületést ünnepelnek" - fejtette ki az interjú során.

A küzdelmi napokon még látni sem bírják egymást az ellenfelek, de a következố napon, mintha mi se történt volna, újból testvéri a 
viszony. „Ez a szokás a vallási felekezetek destruktív ideái ellenére is folytatódni fog, és folytatódnia kell, hiszen ez harc az andoki kultúráért is " folytatta Zecenarro professzor.

A társadalmi kontextuson belül különbözô funkciót ellátó intézmények mellett a rítus az, ami többféle igényt szolgál ki egyszerre: isteneket kiengesztelő, jósló, háborús játékot és bô termést biztosító, szórakoztató stb. közösségi esemény, ahol a távolról érkezett rokonok és barátok találkozhatnak. Másrészt a rítus ma már a meszticek és az indiánok közös játékterének számít. Akár a központi települések és nagyobb falvak, ahol közös az élettér is, a mesztic származásúak száma csak nốtt az utóbbi években. A rítus továbbá az az alkalom, ahol a közösség tagjai ünnepelnek és kitörnek a mindennapok rutinjából, összemérik erejüket, megmutatják bátorságukat, levezetik feszültségüket.

\section{A harci rítusok változása és jövơje}

Természetes, hogy a rítusok, szokások is folyamatosan változnak. Azok változtatnak rajta, akik végzik, részét képezik. Canas megye küzdelmi rítusai közül a Chiaraje a legszemléltetôbb példája a változásoknak, azon belül is az alsó rész, Quehue oldala. Arra hívja fel a figyelmet többek között, hogy a turizmus és kereskedelem hogyan formál át, profanizál évrôl évre egy szakrális eseményt. A pihenôhelyen felhalmozott vásári portékák a turisták igényeit igyekeznek kielégíteni. Az árusok és a tömeg hömpölygésében a küzdelem maga mintha másodlagossá válna. A színhely egy „fieszta” jelleget kap, a turisták számára izgalmas és különleges látványossággal. A Tocto és Mikayo ezzel szemben izoláltabb, itt erósebb a hagyomány (például a népviselet), bár a körtáncok, dalok itt is kezdenek ritkábbá válni.

Pongoñai szállásomon is beszélgettünk a változásokról: „Azelótt lovon vagy szamárháton mentek fel, és csak az otthon elkészitett hideg élelem és nádpálinka volt fönt, most meg már mindent meg lehet venni”- füzte 
hozzá Kamilla asszony. Ez leginkább a Chiarajére jellemzô, ahol a pihenôhely határozottan piactérré alakul a rítus folyamán. A Chiarajén a dalok és a körtáncok kezdenek eltúnni, viszont a parittyák könnyen beszerezhetốk pár solért. 2005-ben egyik rítuson sem láttam körtáncot. Mikor rákérdeztem, mondták, hogy lesz, várjak kicsit. Mégis elmaradt. Egy évvel azelốtt a Chiarajén a hagyományôrzốbb checcai oldalon végre szemtanúja lehettem. Az idôsebb kecsua indiánok közben fújták a pinquyllut, a hosszú inka furulyát, a férfiasság szimbólumát. Melankolikus zenéje mindhárom rítuson felhangzik, hiszen ez a küzdelmek ôsi canasi hangszere.

Szóba került az is, hogy egyes vallási felekezetek és a polgármesteri hivatalok mérsékelni akarják a küzdelem agresszív jellegét. Békés karneváli ünnepet akarnak belôle formálni, mindenféle véres megmozdulást mellózve. (Ezt a törekvést többen a városokban is pártolják, akik barbarizmusnak ítélik ezt a hagyományt.) Nem veszik figyelembe, hogy a rítusok kollektív emlékezetet ôriznek (az óket elnyomó spanyolok elleni függetlenségi mozgalmakat idézik fel már az Inkák ideje óta), másrészt termékenységi célokat szolgálnak az indiánok hite szerint. „Ez nemcsak hagyomány, hanem az andokbeli kultúra része, mely soha nem fog elveszni, mindig élni fog" - szögezte le Manuel. A küzdelem megszüntetése az indiánok szemszögébốl egyet jelentene azzal a veszéllyel, hogy gazdasági egzisztenciájuk, identitásuk és kulturális sajátosságuk bomlásnak indul.

A rítusra az utóbbi években már nem mennek annyian harcolni - hallottam 2005-ben több adatközlôtốl. A checcai polgármester sem megy a Chiarajére, amióta megválasztották. Ezzel azt az álláspontját nyilvánítja ki, hogy nem ért egyet a fellépố erôszakkal. Fố érvként a küzdelem következményeként egyes családok szociális és anyagi helyzetének negatív változásait hozza fel: a családfó elvesztését, és az egzisztenciális körülmények romlását. Ha valaki súlyosan sebesül, lehet, hogy késôbb már dolgozni sem tud. Az is előfordul, hogy el kell eladnia földjét, vagy állatait, hogy gyógykezelését fizetni tudja. 
Halottak az utóbbi idóben már nem nagyon vannak - több beszélgetésben is elhangzott, hogy a rítus egyre finomodik: a fiatalok megfontoltabbak, jobban vigyáznak. „A foglyokat sem ölik meg, mint régen, hanem meggyógyítják, és jól tartják" - fejtette ki valaki. Mások szerint a küzdelem inkább durvább. 2004-2005 óta nekem három halottról van tudomásom. Az elmúlt évtizedekben egy alkalommal akár ennél több haláleset is történt a helyszínen - állítják a résztvevôk. Ha nem is mindig a rítus alatt, de elôfordult már számos esetben, hogy otthonukban vagy kórházban haltak meg a sebesültek, akik leginkább fejsérülést szenvednek. Sokan nem mennek el a helyi (egyébként korszerúen felszerelt) rendelőkbe, hanem megpróbálják saját kezúleg orvosolni a problémát, és ágynak esnek. Gyakran, mikor végül elszállítják óket a tanyákról a városi kórházba, már menthetetlenek, vagy amputáció szükséges.

„Az indiánok addig fognak küzdeni, míg meg nem halnak, mert a gondolkodásmódot nem lehet megváltoztatni” - állítja egy adatközlö. Az emberek ragaszkodnak a kulturális identitáshoz, hisz a kecsua nyelv használata így is eltúnóben van. „Ez egy szokás, amit ezek a népek nem tudnak feledni, mert mélyen az emberek lelkébe vannak vésódve... ez a múlt öröksége” A három harci rítus alkalmával, minden évben felelevenítik a spanyolok elleni háborúk és a faluközösségek közötti területi viták emlékét, szimbiózisban a természet körforgásával, amelyhez áldozatot kell bemutatniuk. Ki kell engesztelniük az isteneket, emlékeztetve óket a kölcsönösségre. Ahogy az egyik fiatal harcos kecsua indián fogalmazott: „Megyünk, hogy ne veszitsük el a szokásainkat, és hogy megvédjük a földünket és a termést, évról évre, mindig elôre." 


\section{Irodalom}

- Anderle Ádám: Vihar a Sierrában. Indián függetlenségi küzdelmek a XVI-XVIII. században. Budapest, Gondolat, 1981

- Appadurai, Arjun: A lokalitás teremtése. In: Regio. 2001/3.

- Arguedas, José Maria: Mély folyók. Budapest, Magvetô, 1973

- Arkush, Elizabeth és Stanish, Charles: Interpreting Conflict in the Ancient Andes. In: Current Antropology, Volume 46, Nr. 1, February 2005

- Barrionuevo, Alfonsina: Chiaraque. In: Allpanchis Phuturinqa No. 3., 1971

- Boglár Lajos: Vallás és antropológia. Szimbiózis, 1995/4

- Brachetti, Angela: La batalla de Chiaraje.In: Revista Anales : Museo de América No. 9, 2001

- Cama, Maximo - Valencia, Abraham: Ritos de competición en los Andes. Pontificia Universidas Católica del Perú. 2003

- Degregori, Carlos Ivan: Etnikai identitás, társadalmi mozgalmak és politikai szerepvállalás Peruban. Replika 29., 1998 március.

- De la Vega, Garcilaso: Inkák és konkisztádorok. Budapest, Gondolat, 1964 p. 29_ 155

- Estermann, José: Teología en el pensamiento andino. In: Revista Boletín del Instituto Estudios Aymaras. No. 49-51, 1995

- Gelencsér Ágnes - Letenyei László - Takács Ildikó: Indián énekeskönyv. Calibra Kiadó, 1994

- Gose, Peter: Sacrifice and the commodity form in the Andes In: MAN Vo. 21 Nr. 2., 1986

- Handbook of the South American Indians Szerk.: Julian H. Steward - The Andean Civilizations United States Goverment printing office Washington Vo. 2, 1947

- Hopkins, Diana: Juego de enemigos. In: Revista Allpanchis Pluturinqa No. 20., 1982

- Letenyei László: Etnikum és hatalom az Andokban. Replika 29., 1998 március

- Miranda, Juan José García: La muerte en la cosmovisón andina In: Al final del camino Lima SIDEA, 1996 
- Remy, Maria Isabel: Los discursos sobre la violencia en los Andes. Algunas reflexiones a proposito del Chiaraje. In: Poder y violencia en los Andes. Cusco: CBC, 1991.

- Topic, John R. - Topic, Theresa Lange: La guerra Mochica. Revista Arqueològico SIAN, no. 4. Universidad Nacional Mayor de Trujillo; 1997.

- Topic, John R. - Topic, Theresa Lange: El Tinku en la interpretación arqueológica. In: Hacia una comprensión conceptual de la guerra andina. Articulo II. http:/ /arqueologia.deperu.com/wamachuko/1997.html

- Topic, John R. - Topic, Theresa Lange: Evidencias Etnograficas y Etnohistoricas. In: Hacia una comprensión conceptual de la guerra andina. Articulo IV. http:// arqueologia.deperu.com/wamachuko/1997.html

- Ujuáry Zoltán: Agrárkultusz. Folklór és Etnográfia 6-Oktatási és kutatási kiadvány, Debrecen, 1981 